\title{
PENGARUH KEPEMIMPINAN DAN KEPUASAN KERJA TERHADAP \\ KINERJA PEGAWAI DINAS PEKERJAAN UMUM KABUPATEN \\ SOLOK SELATAN DENGAN MOTIVASI KERJA SEBAGAI VARIABEL MODERATING
}

\author{
HENDRA RIANTO
}

hendrajonedi@yahoo.co.id

\begin{abstract}
This paper aims are to know about the effect of leadership to the Performance of the Public Works Department employee in South Solok, effect job satisfaction to employee performance at the Department of Public Works South Solok, the effect leadership on work motivation at the Department of Public Works South Solok, the effect of job satisfaction on work motivation at the Department of Public Works South Solok, job satisfaction and leadership on the Performance of the Public Works Department employee in South Solok and What is the impact of motivation on the performance of the Department of Public Works South Solok than Does Work motivation mediates the relationship between leadership and employee performance at the Department of Public Works South Solok

The test results hypothesis find job satisfaction did not significantly affect the variable Performance ( $Y$ ) is this does not mean that the variable Performance ( $Y$ ) Department of Public Works of South Solok not influenced by variable Job satisfaction, but his current condition working satisfaction at the Department of Public Works South Solok has been good. The efforts need to be made in improving the performance ( $Y$ ) in the Office of Public Works South Solok is to maintain existing levels of job satisfaction now and continue to try to improve.
\end{abstract}

\section{PENDAHULUAN}

\subsection{Latar Belakang Masalah}

Tuntutan agar pemerintah senantiasa dapat mewujudkan pemerintahan yang efektif, transparan, akuntabel dan berorientasi kepada hasil merupakan sesuatu yang mutlak dilaksanakan. Hal ini semakin diperkuat dengan lahirnya Instruksi Presiden Nomor 7 Tahun 1999 tentang Akuntabilitas Kinerja Instansi Pemerintah yang diikuti Keputusan Kepala Lembaga Administrasi Negara Nomor
239/IX/6/8/2003 tentang Perbaikan Pedoman Penyusunan Pelaporan Akuntabilitas Kinerja Instansi Pemerintah.

Menghadapi kondisi ini, instansi pemerintah terutama yang menyangkut masalah pelayanan masyarakat, kedepan tentunya menghadapi berbagai tantangan yang semakin berat. Untuk memenuhi tuntutan tersebut Dinas, instansi terkait harus menetapkan tujuan dan sasaran yang akan dicapai sesuai dengan misi dalam rangka mencapai visinya. 
Pada tahun 2014 Dinas Pekerjaan Umum Kabupaten Solok Selatan memiliki 8 (delapan) sasaran yang dirinci lagi menjadi 12 (dua belas) program dengan 41 (Empat Puluh Satu) kegiatan, dimana sebagian dari kegiatan tersebut dapat dilaksanakan, sedangkan sebagian lagi mengalami kendala. Berdasarkan pengukuran kinerja yang dilakukan diperoleh prosentase pencapaian Kinerja Kegiatan Fisik sebesar 95,00\% dan Kinerja Keuangan $87,70 \%$.

Tidak tercapainya target pada kegiatan tersebut disebabkan adanya 5 (Lima) paket kegiatan yang tidak dapat terlaksana, dengan rincian 4 (empat) buah paket pada kegiatan Bidang Bina Marga dan 1 (satu) buah paket pada kegiatan Bidang Pengairan.

Pekerjaan yang tidak dapat terselesaikan sampai dengan akhir tahun anggaran juga memberi kontribusi terhadap capaian kinerja Dinas Pekerjaan Umum pada tahun 2014, paket-paket tersebut terdapat pada kegiatan Bidang Bina Marga sebanyak 13 (tiga belas) buah paket dan pada kegiatan Cipta Karya 3 (tiga) buah paket dengan sisa anggaran yang tidak terserap sebesar Rp 12.104.323.633,-

Salah satu aspek yang penting untuk diperhatikan oleh organisasi terkait dengan peningkatan kinerja adalah masalah kepuasan kerja. Werther dan Davis (1984) mengemukakan bahwa kepuasan kerja adalah kondisi kesukaan atau ketidaksukaan menurut pandangan pegawai terhadap pekerjaannya. Kepuasan anggota organisasi dapat dihubungkan dengan kinerja dan hasil kerja mereka serta imbalan dan hukuman yang mereka terima.

Rendahnya kinerja Dinas Pekerjaan Umum kabupaten Solok Selatan tersebut tidak hanya disebabkan oleh pelaksana semata, tapi juga disebabkan oleh kepemimpinan yang lemah dalam pengawasan dan melaksanakan pekerjaan sehingga pekerjaan yang membutuhkan waktu cukup lama tidak bisa dilaksanakan karena pengambilan keputusan untuk mengesahkan Anggaran Pendapatan dan Belanja Daerah (APBD) yang dituangkan dalam Dokumen Pelaksanaan Anggaran menjadi telat untuk disyahkanoleh pimpinan, sehingga telat pula dalam melaksanakannya.

Disamping itu, rendahnya kinerja juga disebabkan oleh kurang puasnya karyawan ditempat kerja, sehingga banyak karyawan yang telat datang dan pulang cepat, sehingga keberadaannya dikantor menjadi kurang dari jam kerja yang telah ditentukan oleh pemerintah. Hal ini akan berdampak pada kinerja pegawai secara keseluruhan.

Rendahnya kinerja di dinas Pekerjaan umum kabupaten Solok Selatan berdasarkan pengamatan penulis juga disebabkan oleh motivasi kerja, motivasi mempengaruhi hubungan antara kepemimpinan, kepuasan kerja terhadap kinerja, sehingga kedua variabel tersebut tidak berdiri sendiri, tetapi juga disebabkan oleh variabel lainnya.

\subsection{Perumusan Masalah}

Berdasarkan paparan latar belakang masalah tersebut diatas, maka perumusan masalah 
dalam penelitian ini sebagai berikut :

1. Bagaimanakah pengaruh kepemimpinan terhadap Kinerja pegawai pada Dinas Pekerjaan Umum Kabupaten Solok Selatan?

2. Bagaimanakah pengaruh Kepuasan kerja terhadap Kinerja pegawai pada Dinas Pekerjaan Umum Kabupaten Solok Selatan?

3. Bagaimanakah pengaruh Kepemimpinan terhadap Motivasi kerja pada Dinas Pekerjaan Umum Kabupaten Solok Selatan?

4. Bagaimanakah pengaruh Kepuasan kerja terhadap Motivasi kerja pada Dinas Pekerjaan Umum Kabupaten Solok Selatan?

5. Bagaimanakah pengaruh Kepuasan kerja dan Kepemimpinan terhadap Kinerja pegawai pada Dinas Pekerjaan Umum Kabupaten Solok Selatan?

6. Bagaimanakah pengaruh motivasi terhadap kinerja pada Dinas Pekerjaan Umum Kabupaten Solok Selatan?

7. Apakah Motivasi kerja memediasi hubungan antara Kepemimpinan dan Kinerja pegawai pada Dinas Pekerjaan Umum Kabupaten Solok Selatan?

\section{KAJIAN TEORI}

\subsection{Kinerja}

Secara etimologi, kinerja berasal dari kata prestasi kerja (performance).Sebagaimana dikemukakan oleh Mangkunegara (2005:67) bahwa istilah kinerja berasal dari kata job performance atau actual performance (prestasi kerja atau prestasi sesungguhnya yang dicapai seseorang) yaitu hasil kerja secara kualitas dan kuantitas yang dicapai oleh seorang pegawai dalam melaksanakan tugasnya sesuai dengan tanggung jawab yang diberikan kepadanya. Lebih lanjut Mangkunegara (2005:75) menyatakan bahwa pada umumnya kinerja dibedakan menjadi dua, yaitu kinerja individu dan kinerja organisasi. Kinerja individu adalah hasil kerja karyawan baik dari segi kualitas maupun kuantitas berdasarkan standar kerja yang telah ditentukan, sedangkan kinerja organisasi adalah gabungan dari kinerja individu dengan kinerja kelompok.

\subsubsection{Faktor-Faktor yang} Mempengaruhi Kinerja

Menurut Atmosoeprapto (2001: 58), kinerja adalah perbandingan antara keluaran (ouput) yang dicapai dengan masukan (input) yang diberikan. Selain itu, kinerja juga merupakan hasil dari efisiensi pengelolaan masukan dan efektivitas pencapaian sasaran. Oleh karena itu, efektivitas dan efisiensi pekerjaan yang tinggi akan menghasilkan kinerja yang tinggi pula. Untuk memperoleh kinerja yang tinggi dibutuhkan sikap mental yang memiliki pandangan jauh ke depan. Seseorang harus mempunyai sikap optimis, bahwa kualitas hidup dan kehidupan hari esok lebih baik dari hari ini. Sedangkan menurut menurut Sulistiyani dan Rosidah (2003: 223), penilaian kinerja seseorang merupakan kombinasi dari kemampuan, usaha, dan kesempatan 
yang dapat dinilai dari hasil kerjanya.

\subsubsection{Kepemimpinan}

Suatu organisasi yang berhasil dalam mencapai tujuannya serta mampu memenuhi tanggung jawab sosialnya akan sangat tergantung pada para pimpinannya. Apabila pimpinan mampu melaksanakan fungsi-fungsinya dengan baik, sangat mungkin organisasi tersebut akan dapat mencapai sasarannya. Sebab itu organisasi membutuhkan pemimpin yang efektif, yang mempunyai kemampuan mempengaruhi perilaku anggotanya atau anak buahnya. Jadi, seorang pemimpin atau kepala suatu organisasi akan diakui sebagai seorang pemimpin apabila ia dapat mempunyai pengaruh dan mampu mengarahkan bawahannya ke arah pencapaian tujuan organisasi. Begitu pentingnya peran kepemimpinan dalam sebuah organisasi menjadi fokus yang menarik perhatian para peneliti bidang perilaku keorganisasian.

Pengertian tentang gaya kepemimpinan sangat beragam, sesuai dengan pendekatan yang digunakan untuk mendefinisikannya.

Dalam proses pengambilan keputusan seseorang pemimpin memiliki gaya kepemimpinan yang meliputi ciri-ciri partisipatif, konsultatif, delegatif dan instruktif. Ciri-ciri ini gaya kepemimpinan dalam membuat keputusan digambarkan sebagai berikut:

\begin{tabular}{|l|l} 
Partisipasi & Konsultasi \\
\hline
\end{tabular}

\begin{tabular}{|c|c|}
\hline (G3) & (G2) \\
\hline $\begin{array}{l}\text { Delegasi } \\
\text { (G4) }\end{array}$ & $\begin{array}{c}\text { Instruksi } \\
\text { (G 1) }\end{array}$ \\
\hline
\end{tabular}

Kepemimpinan yang diteliti Thoha Tahun 1995.

Dari gambar diatas yang memperlihatkan gaya kepemimpinan dalam pembuatan keputusan dapat dijelaskan sebagai berikut :

a. Perilaku pemimpin yang tinggi pengarah dan rendah dukungan (G1) dirujuk sebagai instruksi, karena gaya ini bercirikan komunikasi satu arah, pemimpin ini memberitahu tentang apa, bagaimana, bilamana, untuk melaksanakan tugas artinya keputusan yang telah dianlbil diumumkan dan diawasi secara ketat.

b. Perilaku pemimpin yang tinggi pengarahan dan tinggi dukungan (G2) dirujuk sebagai konsultasi karena gaya ini bercirikan bahwa pemimpin memberikan pengarahan dan membuat suatu keputusan tetapi diikuti dengan tindakan meningkatkan komunikasi dua arah dan perilaku mendukung, dengan berusaha mendengar perasaan bawahan tentang keputusan yang dibuat, menerima saran dan ide dari bawahan dan mengadakan pengendalian.

c. Perilaku pemimpin yang tinggi dukungan dan rendah 


\begin{abstract}
pengarahan (G3) dirujuk sebagai partisipasi, karena gaya ini bercirikan bahwa antara pemimpin dan bawahan saling tukar menukar ide dalam pemecahan masalah, komunikasi dua arah, peranan pemimpin secara aktif mendengar. Posisi control atas pemecahan masalah dan pembuatan keputusan dipegang secara bergantian.

d. Perilaku pemimpin yang rendah dukungan dan rendah pengarahan (G4) dirujuk sebagai delegasi, karena gaya ini pemimpin mendiskusikan secara bersama-sama atas masalah dengan bawahan sehingga mencapai kesepakatan, pembuatan keputusan didelegasikan secara keseluruhan kepada bawahan, dan bawahan yang mempunyai kewenangan penuh untuk menyelesaikan pekerjaan yang menjadi tugas dan tanggung jawabnya.
\end{abstract}

\subsubsection{Kepuasan Kerja}

Davis dan Newstorm (1997:110) mengemukakan bahwa "Job satisfaction is part of life satisfaction. The nature of one's environment of the job influences one's feeling on the job. Similarly since the job is an important part of life, job satisfaction influences one's general life satisfaction".

Sedangkan factor yang menimbulkan kepuasan kerja seseorang adalah :
a. Kedudukan
b. pangkat dan jabatan

c. masalah umur

d. jaminan financial dan jamunan social

e. mutu pengawasan Sedangkan menurut Moh. Asaad (2000:115) faktor-faktor yang mempengaruhi kepuasan kerja adalah :

a. Faktor psikologis, yaitu faktor yang berhubungan dengan kejiwaan pegawai yang meliputi minat, ketentraman dalam bekerja, sikap terhadap kerja, bakat dan ketrampilan.

b. Faktor Sosial, merupakan faktor yang berhubungan dengan interaksi sosial baik antar sesama pegawai maupun dengan atasan.

c. Faktor Fisik, merupakan faktor yang berhubungan dengan kondisi fisik lingkungan kerja dan kondisi fisik pegawai, jenis pekerjaan, pengaturan waktu kerja, waktu istirahat, perlengkapan kerja, keadaan ruangan, suhu ruangan, penerangan, ventilasi, kondisi kesehatan pegawai dan umur pegawai.

d. Faktor finansial, merupakan faktor yang berhubungan dengan jaminan serta kesejahteraan yang meliputi sistem dan besarnya gaji, jaminan 
sosial, berbagai bentuk tunjangan dan fasilitas yang diberikan.

\section{Pengukuran Kepuasan Kerja}

Menurut Weiss dalam Feldman dan Arnold (1986 : 99) ada 20 (dua puluh) dimensi atau faktor yang dapat dijadikan unsur untuk menilai perasaan puas atau tidak puasnya seorang pegawai terhadap pekerjaannya, yaitu :
a. Ability
Utilazation
b. Achievement
c. Activity
d. Advancement
e. Authority
f. Company policy and practice
g. Compensation
h. Coworkers
i. $\quad$ Creativity
$j$. Independence

k. Moral

Value

l. Recognition

m. Responsibil ity

n. Security

o. Social

Service

p. Social

\subsubsection{Motivasi Kerja}

Terdapat banyak pengertian yang diberikan oleh para penulis tentang motivasi. Di antaranya adalah Robert Heller (1998:6) yang menyatakan bahwa motivasi adalah keinginan untuk bertindak. Setiap orang dapat termotivasi oleh beberapa kekuatan yang berbeda. Di pekerjaan, kita perlu

mempengaruhi bawahan untu menyelaraskan motivasinya dengan kebutuhan organisasi. Motivasi Kerja adalah hasil kumpulan kekuatan internal dan eksternal yang menyebabkan pekerja memilih jalan bertindak yang sesuai dan menggunakan perilaku tertentu. Idealnya, perlaku ini akan diarahkan pada pencapaian tujuan organisasi (Newstrom, 2011 : 109). Robbins dan Judge, McShane dan Von Glinow ( 2010:132) memberikan definisi motivasi sebagai kekuatan dalam diri orang yang mempengaruhi arah (direction), intensitas (intensity) dan ketekunan (persistence) perilaku sukarela. Pekerja yang termotivasi berkeinginan menggunakan tingkat usaha tertentu (intensity), untuk sejumlah waktu tertentu (persistence), terhadap tujuan tertentu (direction). Motivasi merupakan salah satu dari empat pendorong penting perilaku dan kinerja individual. Dinyatakan pula bahwa motivasi merupakan proses psikologis yang mebangkitkan arousal) mengarahkan (direction) dan ketekunan (persistence) dalam melakukan tindakan secara sukarela yang diarahkan pada pencapaian tujuan ( Kreitner dan Kinicki, 2010 : 212).

\section{a. Jenis-jenis Motivasi Kerja}


Jenis-jenis

motivasi kerja :

1. Motivasi Ekstrinsik, yaitu tidakan yang digerakan oleh suatu sebab yang datang dari luar individu, rangsangan dari luar tersebut menggerakkan individu untuk berbuat.

2. Motivasi Instrinsik, yaitu tindakan yang digerakan oleh suatu sebab yang datang dari dalam diri individu (inisiatif), kemudian berdasarkan inisiatif tersebut mencari objek yang relevan (Ilyas, 2000:43)

b. Teori - teori Motivasi

Secara garis besar, teori motivasi dikelompokkan ke dalam tiga kelompok yaitu teori motivasi dengan pendekatan isi/kepuasan (content theory), teori motivasi dengan pendekatan proses (process theory) dan teori motivasi dengan pendekatan penguat (reinforcement theory)

c. Teori Hierarki Kebutuhan Maslow

Kebutuhan dapat didefinisikan sebagai suatu kesenjangan atau pertentangan yang dialami antara satu kenyataan dengan dorongan yang ada dalam diri. Apabila pegawai kebutuhannya tidak terpenuhi maka pegawai tersebut akan menunjukkan perilaku kecewa. Sebaliknya, jika kebutuhannya terpenuhi maka pegawai tersebut akan memperlihatkan perilaku yang gembira sebagai manifestasi dari rasa puasnya.

Kebutuhan merupakan fundamen yang mendasari perilaku pegawai. Karena tidak mungkin memahami perilaku tanpa mengerti kebutuhannya. Abraham Maslow (Mangkunegara, 2005) mengemukakan bahwa hierarki kebutuhan manusia adalah sebagai berikut : 1). Kebutuhan fisiologis (physiological needs), yaitu kebutuhan untuk makan, minum, perlindungan fisik, bernapas, seksual. Kebutuhan ini merupakan kebutuhan tingkat terendah atau disebut pula sebagai kebutuhan yang paling dasar, 2). Kebutuhan rasa aman, (safety needs) yaitu kebutuhan akan perlindungan diri dari ancaman, bahaya, pertentangan, dan lingkungan hidup, 3) Kebutuhan untuk rasa memiliki (sosial), yaitu kebutuhan untuk diterima oleh kelompok, berafiliasi, berinteraksi, dan kebutuhan untuk mencintai serta dicintai, 4) Kebutuhan akan harga diri (esteem needs), yaitu kebutuhan untuk dihormati dan dihargai oleh orang lain dan 5) Kebutuhan untuk mengaktualisasikan diri ( self actualization ), yaitu kebutuhan untuk menggunakan kemampuan, 
skill dan potensi. Kebutuhan untuk berpendapat dengan mengemukakan ide-ide, gagasan dan kritik terhadap sesuatu

d. Teori

dua

\section{Faktor Herzberg}

Teori ini

dikemukakan oleh Frederick Herzberg dengan asumsi bahwa hubungan seorang individu dengan pekerjaan adalah mendasar dan bahwa sikap individu terhadap pekerjaan bias sangat baik menentukan keberhasilan atau kegagalan. (Robbins, 2007).

\section{Teori}

yang

dikembangkannya dikenal dengan "Model Dua Faktor" dari motivasi, yaitu faktor otivasional dan faktor

hygiene atau "pemeliharaan". Menurut teori ini yang dimaksud faktor motivasional adalah hal-hal yang mendorong berprestasi yang sifatnya intrinsik, yang berarti bersumber dalam diri seseorang, sedangkan yang dimaksud dengan faktor hygiene atau pemeliharaan adalah faktor-faktor yang sifatnya ekstrinsik yang berarti bersumber dari luar diri yang turut menentukan perilaku seseorang dalam kehidupan seseorang.

Herzberg memandang bahwa kepuasan kerja berasal dari keberadaan motivator intrinsik dan bawa ketidakpuasan kerja berasal dari ketidakberadaan faktorfaktor ekstrinsik. Faktor- faktor ekstrinsik (konteks pekerjaan) meliputi : (1) Upah, (2) Kondisi kerja, (3) Keamanan kerja, (4) Status, (5) Prosedur instansi, (6) Mutu penyeliaan, (7) Mutu hubungan interpersonal antar sesama rekan kerja, atasan, dan bawahan

\section{Indikator Motivasi Kerja Pegawai}

Menurut Herzbeg dalam wiludjeng (2007:157) indikator motivasi kerja adalah:

1. Achievement (prestasi), ketrampilan dan kemampuan yang dicurahkan pegawai dalam menghadapi kesulitan dan tantangan pekerjaan agar dapat mencapai prestasi kerja yang diharapkan.

2. Recocnition (pengakuan) pegawai mengharapkan pengakuan dari instansi dan lingkungan kerja tempat pegawai bekerja pegawai merasa diakui dan dihargai apabila mereka melaksanakan tanggung jawab pekerjaan dengan baik dan diberi imbalan sesuai pekerjaan yang telah mereka capai.

3. Responsibility (tanggung jawab) tanggung jawab yang dimiliki oleh pegawai terhadap pekerjaan yang diberikan kepada mereka.

4. Challenging work (pekerjaan yang menentang) pegawai merasa tertantang dengan pekerjaan yang dberikan kepada mereka, sehingga pegawai lebih maksimal dan optimal menggunakan 
kemampuan dan ketrampilan yang mereka miliki untuk mencapai kinerjanya.

5. Advancemen (kemajuan), pegawai yang telah menyelesakan pekerjaan dengan baik dan pegawai yang berprestasi bagi instansi dapat menjamin untuk maju kejabatan (posisi) yang lebih tinggi, instansi juga diharapkan memberikan bonus, tunjangan atau penghargaan untuk prestasi kerja yang bagus.

\section{METODE PENELITIAN \\ Objek Penelitian}

Penelitian ini dilakukan dalam lingkup menganalisis pengaruh kepemimpinan dan kepuasan kerja terhadap kinerja pegawai negeri sipil pada Dinas Pekerjaan Umum Kabupaten Solok Selatan. Jumlah sampel adalah 51 orang yang diteliti dari bulan Februari sampai Maret 2016.

\section{Teknik Analisa Data}

Untuk menganalisis data dan pengujian hipotesis, penelititan ini akan menggunakan beberapa teknik dan analisis statistik melalui pemanfaatan Statisticial Package for Social Science (SPSS) versi 16.0 for Windows antara lain adalah :

\section{Analisa Deskriptif}

Statistik deskriptif digunakan untuk menggambarkan atau mendiskripsikan data yang telah dikumpulkan menjadi sebuah informasi (Kuncoro, 2003), misalnya mendeskripsikan profil responden ( jenis kelamin, pendidikan, usia dan lain-lain), kemudian juga menggambarkan nilai rata-rata variabel, distribusi frekuensi jawaban responden terhadap masing-masing pertanyaan pada variabel penelitian. Sekaran (2006), statistik deskriptif merupakan statistik yang menggambarkan fenomena yang menarik perhatian yang meliputi transformasi data mentah kedalam bentuk yang akan memberikan informasi untuk menjelaskan sekumpulan faktor dalam suatu situasi.

Statistik deskriptif perlu dilakukan terhadap penelitian untuk memperkuat argumentasi dan logika dalam jawaban dan mengimplementasikan dengan yang akan dikumpulkan dalam analisa kuantitatif, dilakukan berdasarkan pada data yang dikumpulkan dari daftar pertanyaan (kuesioner) yang telah diajukan dan diisi oleh pegawai Pekerjaan Umum Kab. Solok Selatan (responden).

Dalam analisis data pada penelitian data kualitatif, dianalisis menggunakan teknik analisis deskriptif kualitatif dengan persentase yaitu :

Persentase Skor Rata-Rata $(\mathrm{SR})=$ Jumlah Skor Yang di Capai Jumlah Skor Maksimal x $100 \%$

Dasar yang digunakan untuk menghitung tingkat pemahaman 
responden menurut Sudjana (1996) adalah :

$$
\begin{array}{r}
90-100 \% \rightarrow \text { Baik } \\
70-89 \% \rightarrow \text { Cukup Baik } \\
60-69 \% \rightarrow \text { Kurang Baik } \\
0-59 \% \rightarrow \text { Tidak Baik } \\
\text { Hasil dari pengukuran } \\
\text { variable ini akan dapat ditarik } \\
\text { informasi } \\
\text { implementasi terhadap r butir } \\
\text { variable yang diteliti dalam }
\end{array}
$$$$
\text { penelitian ini. }
$$

\section{HASIL PENELITIAN DAN PEMBAHASAN}

\subsection{Uji Koefisien Korelasi}

Koefisien korelasi merupakan suatu teknik statistik yang digunakan untuk mengukur keeratan hubungan antar variabel (Kuncoro, 2003). Dalam penelitian ini, untuk mengetahui keeratan hubungan antara variabel yaitu variabel Kepuasan Kerja (X1), Kepuasankerja (X2), variabel moderasi Motivasi Kerja (M) dan variabel Kinerja (Y) digunakan korelasi bivariat (bivariate correlation) melalui metode Person's correlation.

Berdasarkan hasil analisa koefisien korelasi antar variable penelitian yang disajikan pada Tabel 4.10 terlihat bahwa variable memiliki hubungan yang korelasinya berkisar antara $0,454-0,689$. Variabel kepemimpinan (X1) berkorelasi kuat terhadap variabel kinerja maupun variabel kepuasan kerja dengan nilai korelasi sebesar 0,671. Hal ini memberikan indikasi bahwa kepuasan kerja memiliki hubungan yang kuat dan erat dengan Kinerja maupun Kepemimpinan.

\subsection{Uji Asumsi Klasik}

Suatu model regresi dikatakan linier harus melaui uji asumsi klasik yang terdiri dari uji linearitas, uji normalitas, uji multikolonieritas dan uji heteroskedastisitas (Ghozali, 2011). Berikut ini akan dilakukan uji asumsi klasik terhadap model regresi sebagai berikut:

\section{a. Uji Linearitas}

Uji linearitas digunakan untuk melihat apakah spesifikasi model yang digunakan sudah benar atau tidak. Untuk menentukan apakah fungsi persamaan regresi yang digunakan berbentuk liner, maka dapat dilihat dari P-P Plot. Apabila titik-titik terdistribusi mengikuti garis linear, maka model regresi dapat dinyatakan linier. Dalam penelitian ini, untuk uji lineritas dipergunakan Grafik P-P Plot. Berdasarkan grafik tersebut yang diperlihatkan dibawah ini, terlihat bahwa titik-titik bergerak menuju searah dengan garis linear, sehingga dapat disimpulkan bahwa model regresi penelitian ini adalah linear.

\section{b. Uji Normalitas}

Uji normalitas bertujuan untuk menguji apakah dalam model regresi, variabel pengganggu atau residual memiliki distribusi normal. Seperti diketahui bahwa uji $t$ dan $F$ mengasumsikan bahwa nilai residual mengikuti distribusi normal. Kalau asumsi ini dilanggar maka uji statistik menjadi tidak valid untuk jumlah sampel kecil. Untuk mendeteksi uji normalitas dapat dilakukan melalui Analisa grafik. Analisa grafik ini dapat digunakan 
untuk menentukan normalitas dengan melihat grafik histogram yang membandingkan antara data observasi dengan distribusi yang mendekati distribusi normal (Ghozali, 2011).

\section{c. Uji Multikolonieritas}

Uji multikolonieritas bertujuan untuk menguji apakah model regresi ditemukan adanya korelasi antar variabel bebas (independent variable). Model regresi yang baik seharusnya tidak terjadi korelasi di antara variabel bebas. Jika variabel bebas saling berkorelasi, maka variabel-variabel tersebut tidak ortogonal. Variabel ortogonal adalah variabel bebas yang nilai korelasi antar sesama variabel bebas sama dengan nol (Ghozali, 2011). Adapun cara untuk mendeteksi ada atau tidaknya multikolonieritas di dalam model regresi melalui nilai tolerence dan variance inflation factor (VIF). Kedua ukuran ini menunjukkan setiap variabel bebas manakah yang dijelaskan oleh variabel bebas lainnya. Dalam pengertian sederhana setiap variabel bebas menjadi variabel terikat dan diregres terhadap variabel bebas lainnya. Nilai cut-off yang umum dipakai untuk menunjukkan adanya multikolonieritas adalah nilai tolerence $<0,10$ atau sama dengan nilai $\quad$ VIF $>10$. Hasil uji multikolonieritas tersebut disajikan pada table berikut ini:

Uji Multikolonieritas

\begin{tabular}{|c|c|c|}
\hline Variabel & $\begin{array}{c}\text { Toler } \\
\text { ance }\end{array}$ & VIF \\
\hline Kepemimpinan $(\mathrm{X} 1)$ & 0.546 & 1.831 \\
\hline
\end{tabular}

\begin{tabular}{|l|l|l|}
\hline Kepuasan Kerja (X2) & 0.546 & 1.831 \\
\hline
\end{tabular}

Berdasarkan hasil uji multikolonieritas yang disajikan pada Tabel 4.15 diatas didapatkannya nilai tolerence untuk semua variabel bebas berada diatas 0,10 . Begitu juga jika dilihat dari nilai VIF (variance inflation factor), tidak satupun dari variabel bebas memiliki nilai VIF diatas 10. Jadi dapat disimpulkan bahwa variabel bebas dalam penelitian ini dinyatakan bebas dari moltikolonieritas.

\section{d. Uji Heteroskedastisitas}

Uji Heteroskedastisitas bertujuan menguji apakah dalam model regresi terjadi ketidaksamaan varian dari residual satu pengamatan ke pengamatan yang lain. Jika varian dari residual satu pengamatan ke pengamatan lain tetap, maka disebut homoskedastisitas dan jika berbeda disebut heteroskedastisitas. Model regresi yang baik adalah yang homoskedastisitas atau tidak terjadi heteroskedastisitas. Untuk mendeteksi ada atau tidaknya heteroskedastisitas dapat dilakukan dengan melihat Garfik Plott (Scatter plot). Jika tidak terdapat pola yang jelas, seperti titik menyebar di atas dan dibawah angka 0 (nol) pada sumbu Y, maka tidak terdapat heteroskedastisitas.

\subsection{Uji Hipotesis Penelitian}

Menurut Sekaran (2003) hypoyhesis is an educated conjucture abut the logically developed relationship between two or more variables, expresses in the form of testable statements. Secara umum definisi tersebut dapat diartikan bahwa hipotesis merupakan dugaan 
tentang hubungan yang logis antara dua variabel atau lebih yang dinyatakan dalam bentuk pernyataan yang perlu diuji kebenarannya.

\section{a. Uji Hipotesis Pertama ( H1) dan Kedua (H2)}

Adapun hipotesis yang telah dikembangkan dalam penelitian ini dapat dilihat sebagai berikut :

H.1. Kepemimpinan berpengaruh signifikan terhadap kinerja pegawai Dinas Pekerjaan Umum Kabupaten Solok Selatan.

H.2. Kepuasan Kerja berpengaruh signifikan terhadap Kinerja pegawai Dinas Pekerjaan Umum Kabupaten Solok Selatan.

Untuk melakukan pengujian hipotesis ini, digunakan analisa regresi linear berganda, dimana analisa regresi linear berganda merupakan tekhnik statistik yang digunakan untuk menguji pengaruh beberapa variable bebas terhadap variable terikat (Sekaran, 2006).

Tujuan menggunakan analisa regresi linear berganda dalam penelitian ini adalah untuk mengetahui pengaruh variabel Kepemimpinan (X1), Kepuasan Kerja (X2) terhadap Kinerja (Y) pada Dinas Pekerjaan Umum Kabupaten Solok Selatan.

Dalam pengujian hipotesis ini, penelitian ini memberikan asumsi bahwa tingkat signifikansi hipotesis alternative yang diterima adalah dibawah 0.05 atau $5 \%$.

Berdasarkan Tabel 4.12 terlihat bahwa nilai koefisien regresi untuk masing-masing variabel bebas adalah sebagai berikut:
1). Nilai koefisien regresi variabel Kepemimpinan (X1) adalah sebesar 0,418 dengan tingkat signifikansi sebesar 0,001 . Besarnya nilai signifikansi tersebut lebih kecil dari 0,050. Dengan demikian, dapat disimpulkan bahwa variabel keepemimpinan (X1) berpengaruh signifikan terhadap kinerja (Y). Oleh karena itu hipotesis H.1. penelitian ini yang menyatakan "Kepemimpinan berpengaruh signifikan terhadap kinerja pegawai Dinas Pekerjaan Umum Kabupaten Solok Selatan" Diterima.

2). Nilai koefisien regresi Variabel Kepuasan kerja (X2) adalah sebesar 0,048 dengan tingkat signifikansi sebesar 0,539 . Besarnya nilai signifikansi tersebut lebih besar dari 0,050. Dengan demikian, dapat disimpulkan bahwa Variabel kepuasan kerja (X2) tidak berpengaruh signifikan terhadap Kinerja (Y). Oleh karena itu hipotesis H.2. penelitian ini yang menyatakan "kepuasan kerja berpengaruh signifikan terhadap kinerja pegawai Dinas Pekerjaan Umum Kabupaten Solok Selatan" Ditolak.

3). Nilai F adalah sebesar 13.775 dengan tingkat signifikansi sebesar 0,000 atau lebih kecil dari 0,05. Dengan demikian, dapat disimpulkan bahwa variabel Kepemimpinan (X1), dan kepuasan kerja (X2) secara simultan berpengaruh signifikan terhadap Kinerja.

4). Nilai $\mathrm{R}^{2}(R \quad$ square $)$ atau koefisien determinan adalah 
0.360. Besarnya nilai tersebut dapat diinterpretasikan bahwa variabel Kinerja (Y) dijelaskan oleh variabel Kepemimpinan (X1), dan Kepuasan Kerja (X2) adalah sebesar $36.0 \%$. Dengan kata lain, pengaruh variabel Kinerja (Y) dijelaskan oleh variabel Kepemimpinan (X1), dan Kepuasan Kerja (X2) terhadap Kinerja (Y) adalah sebesar $36.0 \%$. Sedangkan sisanya sebesar $64.0 \%$ dipengaruhi oleh variable lain yang tidak termasuk kedalam lingkup penelitian ini.

\section{Pembahasan}

Bagian ini berisikan pembahasan mengenai pengaruh masing-masing variable bebas yaitu Kepemimpinan dan kepuasan Kerja terhadap Kinerja pegawai Dinas Pekerjaan Umum Kabupaten Solok Selatan.

\section{a. Pengaruh Kepemimpinan Terhadap Kinerja}

Hasil analisa statistik diperoleh nilai rata-rata variabel Kepemimpinan sebesar 3.86 dengan TCR sebesar $81.8 \%$. Hal ini dapat diartikan bahwa Kepemimpinan di Kantor Dinas Pekerjaan Umum Kabupaten Solok Selatan dalam kategori cukup puas.

Sedangkan berdasarkan analisa statistik diperoleh nilai ratarata Kinerja sebesar 4.10 dengan TCR sebesar $82.0 \%$. Hal ini dapat diartikan bahwa Kinerja di Dinas Pekerjaan Umum Kabupaten Solok Selatan dalam kategori cukup tinggi.

Berdasarkan hasil uji hipotesis tentang pengaruh Kepemimpinan dan kepuasan Kerja terhadap Kinerja pada Dinas Pekerjaan Umum Kabupaten Solok Selatan, hasil penelitian ini menemukan variable kepemimpinan berpengaruh positif dan signifikan terhadap Kinerja, sedangkan variabel Kepuasan kerja tidak berpengaruh signifikan terhadap Kinerja. Koefisien regresi bertanda positif menunjukan terjadinya hubungan yang searah dari Kepuasan Kerja dan Kepemimpinan terhadap Kinerja. Hal ini bermakna semakin baik implementasi Kepuasan Kerja pada Dinas Pekerjaan Umum Kabupaten Solok Selatan dimasa yang akan datang, maka akan semakin tinggi pula Kinerja Dinas Pekerjaan Umum Kabupaten Solok Selatan. Sebaliknya semakin buruk implementasi Kepemimpinan pada Dinas Pekerjaan Umum Kabupaten Solok Selatan dimasa yang akan datang, maka akan semakin rendah pula Kinerja Dinas Pekerjaan Umum Kabupaten Solok Selatan.

Hasil penelitian ini konsisten dengan hasil penelitian empiris terdahulu yang dilakukan oleh Said Musnadi Maulidar dan Mukhlis Yunus (2012) yang berjudul " Pengaruh Kepemimpinan Dan Kepuasan Kerja Terhadap Motivasi Kerja Dan Dampaknya Terhadap Kinerja Pegawai Dinas Perindustrian Perdagangan Koperasi Dan Usaha Kecil Menengah Aceh". Penelitian tersebut menemukan bahwa secara parsial variabel Kepuasan kerja berpengaruh positif terhadap kinerja.

Hasil penelitian ini juga konsisten dengan hasil penelitian empiris terdahulu yang dilakukan oleh Shandy Marsono (2012) yang berjudul " Pengaruh Kepemimpinan, Motivasi Dan Kepuasan Kerja 
Terhadap Kinerja Guru Smp Negeri II Jaten Kab. Karanganyar". Penelitian tersebut juga menemukan bahwa secara parsial variabel Kepuasan kerja berpengaruh positif terhadap kinerja.

Besarnya pengaruh variabel Kepuasan Kerja dan Kepuasankerja secara simultan terhadap Kinerja Dinas Pekerjaan Umum Kabupaten Solok Selatan adalah sebesar 36.0 $\%$. Hal ini bermakna bahwa Kinerja Dinas Pekerjaan Umum Kabupaten Solok Selatan ditentukan oleh variabel Kepuasan Kerja dan Kepemimpinan adalah sebesar 36.0 $\%$. Sedangkan sisanya sebesar 64.0 $\%$ dipengaruhi oleh variable lain yang tidak termasuk kedalam lingkup penelitian ini.

\section{b. Pengaruh Kepuasan Kerja Terhadap Kinerja}

Berdasarkan analisa statistik diperoleh nilai rata-rata variabel kepuasan kerja kerja sebesar 3.86 dengan TCR sebesar 77.2\%. Hal ini dapat diartikan bahwa Kepuasan kerja di Kantor Dinas Pekerjaan Umum Kabupaten Solok Selatan dalam kategori cukup tinggi.

Sedangkan berdasarkan analisa statistik diperoleh nilai ratarata Kinerja sebesar 4.10 dengan TCR sebesar $82.0 \%$. Hal ini dapat diartikan bahwa Kinerja di Dinas Pekerjaan Umum Kabupaten Solok Selatan dalam kategori cukup tinggi.

Berdasarkan hasil uji hipotesis tentang pengaruh Kepemimpinan dan Kepuasan kerja terhadap Kinerja pada Dinas Pekerjaan Umum Kabupaten Solok Selatan, hasil penelitian ini menemukan variable Kepuasan Kerja berpengaruh positif dan signifikan terhadap Kinerja, sedangkan variabel Kepuasan kerja tidak berpengaruh signifikan terhadap Kinerja.

Adapun hasil uji hipotesis yang menemukan Kepuasan kerja tidak berpengaruh signifikan terhadap Kinerja, hal ini bukan berarti bahwa Kinerja Dinas Pekerjaan Umum Kabupaten Solok Selatan tidak dipengaruhi oleh variable Kepuasankerja, tetapi saat ini kondisi Kepuasan kerja pada Dinas Pekerjaan Umum Kabupaten Solok Selatan telah baik. Adapun upaya yang perlu dilakukan dalam meningkatkan Kinerja pada Dinas Pekerjaan Umum Kabupaten Solok Selatan adalah dengan menjaga kondisi kepuasan kerja kerja yang ada sekarang dan terus berusaha meningkatkannya.

Hasil penelitian ini konsisten dengan hasil penelitian empiris terdahulu yang dilakukan oleh Rachmat Yakin (2004) yang berjudul "Analisis Hubungan Antara Sistem Kepuasan kerja Terhadap Motivasi dan Kinerja Karyawan Bagian Produktivitas Produksi PT. Sariwangi A.E.A". Penelitian tersebut menunjukkan bahwa Kepuasankerja tidak mempunyai hubungan dengan kinerja.

Besarnya pengaruh variabel Kepuasan Kerja dan Kepuasan kerja secara simultan terhadap Kinerja Dinas Pekerjaan Umum Kabupaten Solok Selatan adalah sebesar 36.0 $\%$. Hal ini bermakna bahwa Kinerja Dinas Pekerjaan Umum Kabupaten Solok Selatan ditentukan oleh variabel Kepuasan kerja dan Kepemimpinan adalah sebesar 36.0 $\%$. Sedangkan sisanya sebesar 64.0 $\%$ dipengaruhi oleh variable lain 
yang tidak termasuk kedalam lingkup penelitian ini.

\section{c. Pengaruh Motivasi Kerja Terhadap Kinerja}

Berdasarkan analisa statistik diperoleh nilai rata-rata variabel Motivasi Kerja adalah sebesar 3.76 dengan TCR sebesar 75.2\%. Hal ini dapat diartikan bahwa Motivasi Kerja di Dinas Pekerjaan Umum Kabupaten Solok Selatan dalam kategori cukup baik.

Sedangkan berdasarkan analisa statistik diperoleh nilai ratarata Kinerja sebesar 4.10. Hal ini dapat diartikan bahwa Kinerja di Dinas Pekerjaan Umum Kabupaten Solok Selatan dalam kategori cukup baik.

Berdasarkan hasil uji hipotesis tentang pengaruh Motivasi Kerja terhadap Kinerja pada Dinas Pekerjaan Umum Kabupaten Solok Selatan, hasil penelitian ini menemukan Motivasi Kerja berpengaruh signifikan terhadap Kinerja. Koefisien regresi bertanda positif menunjukan terjadinya hubungan yang searah dari Motivasi Kerja terhadap Kinerja. Hal ini bermakna semakin baik implementasi Motivasi Kerja pada Dinas Pekerjaan Umum Kabupaten Solok Selatan dimasa yang akan datang, maka akan semakin tinggi pula Kinerja Dinas Pekerjaan Umum Kabupaten Solok Selatan. Sebaliknya semakin buruk implementasi Motivasi Kerja pada Dinas Pekerjaan Umum Kabupaten Solok Selatan dimasa yang akan datang, maka akan semakin rendah pula Kinerja Dinas Pekerjaan Umum Kabupaten Solok Selatan
Hasil penelitian ini konsisten dengan hasil penelitian empiris terdahulu yang dilakukan oleh Said Musnadi Maulidar dan Mukhlis Yunus (2012) yang berjudul " Pengaruh Kepemimpinan Dan Kepuasan Kerja Terhadap Motivasi Kerja Dan Dampaknya Terhadap Kinerja Pegawai Dinas Perindustrian Perdagangan Koperasi Dan Usaha Kecil Menengah Aceh". Penelitian tersebut menemukan bahwa ada hubungan yang signifikan antara variabel Motivasi Kerja terhadap Kinerja karyawan.

Hasil penelitian ini tidak konsisten dengan hasil penelitian empiris terdahulu yang dilakukan oleh Shandy Marsono (2012) yang berjudul "Pengaruh Kepemimpinan, Motivasi Dan Kepuasan Kerja Terhadap Kinerja Guru Smp Negeri II Jaten Kab. Karanganyar". Penelitian tersebut menemukan bahwa Kepemimpinan berpengaruh negative dan tidak signifikan terhadap kinerja.

\section{d. Pengaruh Motivasi Kerja Memoderasi Hubungan Antara Kepuasan kerja, Kepemimpinan dan Kinerja}

Berdasarkan analisa statistik diperoleh nilai rata-rata variabel Motivasi Kerja adalah sebesar 3.76 dengan TCR sebesar 75.2\%. Hal ini dapat diartikan bahwa Motivasi Kerja di Dinas Pekerjaan Umum Kabupaten Solok Selatan dalam kategori cukup baik.

Hasil analisa statistik diperoleh nilai rata-rata variabel kepuasan kerja sebesar 3.86 dengan TCR sebesar $81.8 \%$. Hal ini dapat diartikan bahwa Kepuasan Kerja di 
Dinas Pekerjaan Umum Kabupaten Solok Selatan dalam kategori cukup puas.

Sedangkan berdasarkan analisa statistik diperoleh nilai ratarata Kinerja sebesar 4.10 dengan TCR sebesar $82.0 \%$. Hal ini dapat diartikan bahwa Kinerja di Dinas Pekerjaan Umum Kabupaten Solok Selatan dalam kategori cukup tinggi.

Berdasarkan hasil analisis MRA (Moderated Regression Analysis) yang digunakan untuk mengetahui pengaruh variabel Motivasi Kerja (M) sebagai variabel moderasi pada hubungan antara variabel kepemimpinan (X1) dan kepuasan kerja (X2) terhadap kinerja (Y), ditemukan pada model MRA 3 dapat dilihat variabel X1M (interaksi antara kepuasan kerja dan Motivasi Kerja) memiliki nilai signifikansi sebesar 0.009. Nilai tersebut lebih kecil dari $(\alpha) 0,05$. Dengan demikian dapat disimpulkan bahwa Motivasi Kerja berperan sebagai variabel moderasi pada pengaruh kepuasan kerja terhadap kinerja. Disamping itu Pada model 1 ditemukan nilai koefisien regresi variabel kepuasan kerja (X1) adalah 0.503, sedangkan nilai koefisien regresi variabel interaksi antara variabel kepuasan kerja dan Motivasi Kerja (X1M) pada model 3 adalah 0.009. sehingga dapat disimpulkan bahwa nilai koefisien regresi variabel interaksi X1M pada model 3 lebih besar dari nilai koefisien regresi variabel $\mathrm{X} 1$ pada model 1. Dengan demikian dapat disimpulkan bahwa variabel Motivasi Kerja memperkuat pengaruh kepemimpinan terhadap kinerja. Hal ini dalam pengertian lain jika semakin tinggi

\section{e. Pengaruh Motivasi Kerja Memoderasi Hubungan Antara Kepuasan kerja dan Kinerja}

Berdasarkan analisa statistik diperoleh nilai rata-rata variabel Motivasi Kerja adalah sebesar 3.76 dengan TCR sebesar 75.2\%. Hal ini dapat diartikan bahwa Motivasi Kerja di Dinas Pekerjaan Umum Kabupaten Solok Selatan dalam kategori cukup baik.

Berdasarkan analisa statistik diperoleh nilai rata-rata variabel kepuasankerja kerja sebesar 3.86 dengan TCR sebesar 77.2\%. Hal ini dapat diartikan bahwa Kepuasan kerja di Dinas Pekerjaan Umum Kabupaten Solok Selatan dalam kategori cukup tinggi.

Sedangkan berdasarkan analisa statistik diperoleh nilai ratarata Kinerja sebesar 4.10 dengan TCR sebesar $82.0 \%$. Hal ini dapat diartikan bahwa Kinerja di Dinas Pekerjaan Umum Kabupaten Solok Selatan dalam kategori cukup tinggi. Berdasarkan hasil analisis MRA (Moderated Regression Analysis) yang digunakan untuk mengetahui pengaruh variabel Motivasi Kerja (M) sebagai variabel moderasi pada hubungan antara variabel kepemimpinan (X1) dan kepuasan kerja (X2) terhadap kinerja (Y), ditemukan pada model MRA 3 dapat dilihat variabel X2M (interaksi antara kepuasan kerja kerja dan Motivasi Kerja) memiliki nilai signifikansi sebesar 0.602. Nilai tersebut lebih besar dari $(\alpha) 0,05$. Dengan demikian dapat disimpulkan bahwa Motivasi Kerja tidak berperan sebagai variabel moderasi pada pengaruh kepuasankerja kerja terhadap kinerja. 


\subsection{Implikasi}

Berdasarkan hasil uji
hipotesis tentang pengaruh Kepemimpinan dan Kepuasan Kerja terhadap Kinerja pada Dinas Pekerjaan Umum Kabupaten Solok Selatan, hasil penelitian ini menemukan hanya variable Kepemimpinan yang berpengaruh signifikan terhadap Kinerja. Koefisien regresi bertanda positif menunjukan terjadinya hubungan yang searah dari Kepemimpinan terhadap Kinerja. Hal ini bermakna semakin baik implementasi Kepemimpinan pada Dinas Pekerjaan Umum Kabupaten Solok Selatan dimasa yang akan datang, maka akan semakin tinggi pula Kinerja Dinas Pekerjaan Umum Kabupaten Solok Selatan. Sebaliknya semakin buruk implementasi Kepemimpinan pada Dinas Pekerjaan Umum Kabupaten Solok Selatan dimasa yang akan datang, maka akan semakin rendah pula Kinerja Dinas Pekerjaan Umum Kabupaten Solok Selatan.

Implikasi dari penelitian ini adalah untuk meningkatkan Kinerja perlu peningkatan pada variabel Kepemimpinan, dengan cara meningkatkan item butir pertanyaan yang dibawah rata-rata variabel. Untuk itu perlu prioritas perhatian pada hal-hal berikut :

1. Atasan memberikan kepercayaan kepada pegawai untuk mengerjakan pekerjaan yang tidak diberikan kepada pegawai lain.

2. Atasan memberikan kepercayaan kepada pegawai jika pegawai dapat menyelesaikan pekerjaan sesuai target yang ditetapkan.

3. Atasan memberikan kepercayaan kepada pegawai bekerja dengan kemampuan yang saya miliki.

4. Memberi kesempatan kepada pegawai untuk mengerjakan pekerjaan yang menantang kemampuan mereka.

Adapun hasil uji hipotesis yang menemukan Kepuasan kerja tidak berpengaruh signifikan terhadap variabel Kinerja (Y) adalah hal ini bukan berarti bahwa variabel Kinerja (Y) Dinas Pekerjaan Umum Kabupaten Solok Selatan tidak dipengaruhi oleh variable Kepuasan kerja, tetapi saat ini kondisi Kepuasankerja pada Dinas Pekerjaan Umum Kabupaten Solok Selatan telah baik. Adapun upaya yang perlu dilakukan dalam meningkatkan Kinerja (Y) pada Kantor Dinas Pekerjaan Umum Kabupaten Solok Selatan adalah dengan menjaga tingkat Kepuasan kerja yang ada sekarang dan terus berusaha meningkatkannya.

\section{PENUTUP}

\subsection{Kesimpulan}

Berdasarkan analisa data dan interpretasi yang telah disampaikan pada bab sebelumnya, maka dapat dikemukakan beberapa kesimpulan dari hasil penelitian ini sebagai berikut:

1. Kepemimpinan berpengaruh signifikan terhadap kinerja pegawai Dinas Pekerjaan Umum Kabupaten Solok Selatan. 
2. Kepuasan kerja tidak berpengaruh signifikan terhadap Kinerja pada Dinas Pekerjaan Umum Kabupaten Solok Selatan.

3. Motivasi Kerja berpengaruh signifikan terhadap kinerja pegawai Dinas Pekerjaan Umum Kabupaten Solok Selatan.

4. Motivasi Kerja memperkuat pengaruh kepemimpinan terhadap kinerja pegawai Dinas Pekerjaan Umum Kabupaten Solok Selatan.

5. Kepuasan kerja dan Kepemimpinan berpengaruh signifikan terhadap Kinerja pegawai pada Dinas Pekerjaan Umum Kabupaten Solok Selatan.

6. motivasi berpengaruh terhadap kinerja pada Dinas Pekerjaan Umum Kabupaten Solok Selatan.

7. Motivasi Kerja tidak memperkuat pengaruh kepuasan kerja terhadap kinerja pegawai Dinas Pekerjaan Umum Kabupaten Solok Selatan.

\subsection{Saran-Saran}

Hasil penelitian ini diharapkan akan memberikan bermanfaat pada pihak Pengambil kebijakan yaitu Pimpinan Dinas Pekerjaan Umum Kabupaten Solok Selatan Saran praktis berdasarkan dari hasil penelitian ini adalah sebagai berikut:

1. Untuk meningkatkan Kinerja di Dinas Pekerjaan Umum Kabupaten Solok Selatan dimasa yang akan datang, maka perlu diperhatikan Motivasi Kerja. Hal ini disebabkan karena Motivasi Kerja berpengaruh signifikan terhadap Kinerja di Dinas Pekerjaan Umum Kabupaten Solok Selatan.
2. Untuk meningkatkan Motivasi Kerja, maka Kantor Kesyahbandaran dan Otoritas Pelabuhan Teluk Bayur perlu meningkatkan implementasi Kepuasan Kerja. Hal ini disebabkan Kepuasan Kerja berpengaruh secara signifikan baik terhadap Motivasi Kerja maupun terhadap Kinerja di Dinas Pekerjaan Umum Kabupaten Solok Selatan.

3. Dalam upaya meningkatkan implementasi Kepuasan Kerja di Dinas Pekerjaan Umum Kabupaten Solok Selatan, hendaknya dengan memberikan prioritas pada :

a. Atasan memberikan kepercayaan kepada pegawai untuk mengerjakan pekerjaan yang tidak diberikan kepada pegawai lain.

b. Atasan memberikan kepercayaan kepada pegawai jika pegawai dapat menyelesaikan pekerjaan sesuai target yang ditetapkan. c. Atasan memberikan kepercayaan kepada pegawai bekerja dengan kemampuan yang saya miliki.

d. Memberi kesempatan kepada pegawai untuk mengerjakan pekerjaan yang menantang kemampuan mereka.

\section{DAFTAR PUSTAKA}

Yudistira, D. S., \& Susanti, F. (2019). Pengaruh Motivasi Kerja Dan Budaya Kerja Terhadap Kinerja Karyawan Dinas Pemberdayaan Masyarakat Dan Desa, Pengendalian Penduduk 
Dan Keluarga Berencana Kabupaten Pesisir Selatan. https://doi.org/10.31227/osf. io/jk54m

Ridho, M., \& Susanti, F. (2019). Pengaruh Stres Kerja Dan Motivasi Kerja Terhadap Kepuasan Kerja Pada Karyawan Bank Mandiri Syariah Cabang Padang. https://doi.org/10.31227/osf. io/pa2cg

Lubis, A. Y. O., \& Susanti, F. (2019). Pengaruh Gaya Kepemimpinan Dan Kompensasi Terhadap Prestasi Kerja Karyawan (Studi pada PT Japfa Comfeed Indonesia (JCI) Tbk Devisi Fam 1. https://doi.org/10.31227/osf. io/7tbrg

Aldi, Y., \& Susanti, F. (2019). Pengaruh Stress Kerja Dan Motivasi Kerja Terhadap Prestasi Kerja Karyawan Pada PT. Frisian Flag Indonesia Wilayah Padang. https://doi.org/10.31227/osf. io/et4rn

Widodo, B. H., \& Susanti, F. (2019). Pengaruh Human Relation (Hubungan Antar Manusia), Lingkungan kerja Terhadap Etos Kerja karyawan (Studi Kasus Pada PT. Pelindo Teluk Bayur Padang ). https://doi.org/10.31227/osf. io/dxm8a

Junaidi, R., \& Susanti, F. (2019). Pengaruh Gaya Kepemimpinan Dan Budaya Organisasi Terhadap Kinerja Pegawai Pada UPTD Baltekkomdik Dinas
Pendidikan Provinsi

Sumatera Barat.

https://doi.org/10.31227/osf. io/bzq75

Selamat, S. Heryanto, H. (2019). Affecting Factors In Employee Performance Koto Baru Sub-District, Dharmasraya District. Archives of Business Research 7 (7), 142-154

Ermayenti, E. Heryanto, H. (2019). The Effect Of Competence And Discipline Of Work On Public Satisfaction In The Regional Office Of The Ministry Of Religion In West Sumatera Province With Quality Of Service As An Intervening Variable. Archives of Business Research 7 (7), 69-87

Kurniawan, H. Heryanto, H. (2019). Effect of Work Discipline and Work Environment on Employee Performance with Work Motivation as an Intervening Variable in Department of Tourism, Youth and Sport of Padang District. Archives of Business Research 7 (7), 88101

Sari, N. Heryanto, H. (2019). The Effect Of Training And Utilization Of SIPKD On Competency And Its Impact On The Quality Of Financial Statements In Dharmasraya Regency SKPD. Archives of Business Research 7 (7), 112-121

Fatra, A. Heryanto, A. (2019). The Effect Of Implementation 
Of

Population

Administration Policy And Employee Motivation On Quality Of Service And Its Impact On Community Satisfaction In Issuance Of Birth ACCESS (Case in: The Department of Population and Civil Registration of the Dharmasraya Regency). Archives of Business Research 7 (7), 155-165

Yusrisal, Y. Heryanto, H.( 2019). The Influence of Leadership and Competence on Work Motivation and its impact on Employee Performance at the Koto Besar SubDistrict Office, Dharmasraya Regency. Archives of Business Research 7 (7), 122-131

Syukri, M. Heryanto, H. (2019). The Influence Of Leadership Style, And Organizational

Commitment, On Employee Discipline And Also Its Impact On Employee Performance Of The Dharmasraya District Community And Village Empowerment Office. Archives of Business Research 7 (7), 102-111

Septria, D. Heryanto, H. (2019). Performance Capability Analysis and Regional Budget Evaluation in Implementing Regional Autonomy in Dharmasraya District. Archives of Business Research 7 (7), 180-187
Meldi, M. Heryanto, H. (2019). The Influence Of Quality Of Human Resources And Communication On The Performance Of Civil Servants In The Regional Secretariat Of Dharmasraya Regency With Organizational Commitment As Intervening Variables. Archives of Business Research 7 (7), 132-141

Wahyuni, N. Heryanto, H. (2019). The Effect of Environment and Motivation on Employee Performance with Organizational Culture as an intervening variable on Bank Perkreditan Rakyat Jorong Kampung Tangah Pariaman PT. Archives of Business Research 7 (5)

Khamri, A. Heryanto, H. (2019). The Influence of the Work Environment, Work Discipline on the Spirit of Work and Its Impact on Employee Performance at the Dharmasraya District Health Office. Archives of Business Research 7 (5)

Irvan, RM. Heryanto, H. (2019). The Effect of Competence and Workload on Motivation and Its Impact on the Performance of Civil Servants at the Regional Secretariat of the Regency of Dharmasraya. Archives of Business Research 7 (5)

Jamilus, J. Heryanto, H. (2019). The Effect of Competence, Communication \& Motivation on Employee Performance in People's Welfare Regional 
Secretariat of Padang City, Indonesia. Archives of Business Research 7 (5)

Zukriah, A. Heryanto, H. (2019). The Effect Of Work Motivation And Discipline On Employee Performance In Human Resources Development Agency, West Sumatera With Education And Training As Variable Intervening. Archives of Business Research 7 (5)

Marunduri, P. Heryanto, H. (2019). Analysis of the Effect of Training and Motivation on Organizational

Commitments and Its Impact on Employee Performance (Study on Insurance Marketing Agents on Prudential Agency PruAini Gunung Sitoli PT). Archives of Business

Syamsudirman, S. Yurmain, H. Heryanto, H. (2019). Compensation and Work Culture on Organizational Performance with in mediation by Work Satisfaction in Fire Department Service of Sungai Penuh City. Archives of Business Research 7 (2)

Heryanto, H. (2019). The Effect of Work Motivation and Work Environment on Performance With Satisfaction as Intervening Variables Education Personnel Rektorate Andalas University. Archives of Business Research 7 (2)
Heryanto, H. Sumarni, S. (2019). The Effect of Certification, Competence, and Motivation on Teachers Performance of Country Civil Apparatus in Sawahlunto City. Archives of Business Research 7 (1)

Eliza, Y. (2015). Pengaruh moralitas individu dan pengendalian internal terhadap kecenderungan kecurangan akuntansi (Studi Empiris Pada SKPD di Kota Padang). Jurnal Akuntansi (Media Riset Akuntansi \& Keuangan) 4 (1), 86-100

Eliza, Y. (2015). Pengaruh Investasi, Angkatan Kerja dan Pengeluaran Pemerintah terhadap Pertumbuhan Ekonomi di Sumatera Barat. PEKBIS (Jurnal Pendidikan Ekonomi Dan Bisnis) 7 (3), 198-208

Eliza, Y. Adriani, E. Maryanti, S. (2019). The Analysis Return on Investment Education of Married Woman in Indonesia. KnE Social Sciences, 667-688-667-688 Maryanti, S. Eliza, Y. Wiyati, R. Thamrin, M. (2018). The Growth of the Population: Labor Potential Mapping in Pekanbaru Indonesia. IOP Conference Series: Earth and Environmental Science 175 (1), 012092

Eliza, Y. (2015). Analisis Kepuasan Masyarakat Atas Kualitas Pelayanan Kantor Kecamatan Siberut Selatan Kabupaten Kepulauan Mentawai. Jurnal 
Pendidikan Ekonomi dan Bisnis 7 (1), 65-75

Yuharmain, H. Suryana, Y. Novianty, R, Joeliaty. (2016). An Impact Study Of Rural Credit Bank Existence Towards Micro And Small Businesses In Padang City. International Journal Of Scientific \& Technology Research 5 (7), 145-150

Edasa, D. Putra, EE. (2015). Pengaruh Gaya Kepemimpinan, Lingkungan Kerja dan Motivasi Kerja Terhadap Kinerja Pegawai LPP-RRI Bukittinggi. Jurnal Riset Manajemen Bisnis dan Publik 3 (2)

Putra, EE. (2015). Keadilan Dalam Organisasi. Buletin Organisasi dan Aparatur

Putra, EE. (2015). Pentingnya ISO Bagi Lembaga Pendidikan Dan Latihan. Buletin Badan Diklat Prov. Sumatera Barat

Putra, EE. (2015). Urgensi Pengembangan Potensi Aparatur Sipil Negara (ASN). Buletin Badan Diklat Prov. Sumatera Barat Putra, EE. (2014). The Effect of Human Capital, Structural and Customer Capital to Performance of Small Medium Enterprises at West Sumatera Province. Business Administration at Jose Rizal University

Putra, RY. Marlius, D. (2019). Pengaruh Pendidikan, Pengalaman Kerja dan Etos Kerja Terhadap Kinerja Pegawai Di KPN Batur.
Academic Conference For Management 2.

Marlius, D. RD Putra. (2018).

Strategi Pengembangan

Sulam Bayang. Jurnal

Benefita: Ekonomi

Pembangunan Manajemen

Bisnis Dan Akuntansi.

Volume 3. No. 2. Hal. 204-

218. 